\title{
Um olhar estrangeiro sobre a obra de Clarice Lispector. Leitura e recepção da autora na França e no Canadá (Quebec).
}

\author{
Lúcia Peixoto Cherem \\ Tese de Doutoramento \\ Universidade de São Paulo \\ Orientadora: Glória Carneiro do Amaral
}

A recepção da literatura brasileira no exterior tem sido estudada no mundo acadêmico, mas ainda é um assunto pouco divulgado. Há poucas publicações de fôlego que tratam da maneira como os autores brasileiros são lidos fora de seu local de produção. Lúcia Peixoto Cherem aborda a questão da recepção de Clarice Lispector na França e no Quebec, tema muito relevante, já que se sabe que Clarice é uma escritora que tem devotos em vários países, sobretudo no mundo de língua francesa.

Trata-se de uma tese que se lê com interesse e prazer porque é bem escrita, organizada, articulada, além de demonstrar muita maturidade intelectual e humana. A tese é ilustrada com reproduções de quadros, escolhidos com muita propriedade, nos inícios de capítulos e algumas vezes no meio deles.

Apesar de o título apontar tão-somente para a questão da recepção, a tese é híbrida, pois a autora também analisa aspectos da obra de Clarice Lispector, assim como algumas traduções publicadas em francês. A recepção está fundamentalmente nos capítulos 1 e 5 ; a análise literária se encontra sobretudo no capítulo 2 , que trata da espiritualidade, e no capítulo 3, que aborda as relações da literatura com as artes plásticas e a música; a questão da tradução é considerada principalmente no capítulo 4. O caráter híbrido confere à tese uma forma de mosaico, resultado da tentativa da autora de captar tantas facetas da obra de Clarice, sem perder nenhuma delas. A escolha de tentar dar conta de tudo tem um lado positivo, embora o aspecto negativo seja preponderante, pois o trabalho se estende demais e não chega a esgotar o cerne de sua proposta. A tese teria ganho se tivesse explorado mais a questão da recepção, utilizando material publicado pela imprensa e, inclusive, comparando a recepção da obra de Clarice com aquela de outros autores brasileiros na França.

Lúcia Cherem destaca a importância de Hélène Cixous para a recepção de Clarice Lispector em francês, pois foi através de seus seminários na Universidade de Paris que muitas pessoas tiveram acesso à obra da escritora brasileira, entre as quais as autoras Claire Varin, Monique Bosco 
e Louise Dupré, todas do Quebec. A própria autora da tese afirma ter assistido a um desses seminários. Durante o doutorado, ela teve a oportunidade de entrar em contato com as autoras do Quebec por ter obtido uma bolsa sanduíche na Université du Québec à Montreal (UQAM), tendo inclusive traduzido o livro de Claire Varin sobre Clarice para o português. Além de ressaltar a atuação de Hélène Cixous como professora, a tese também lembra sua participação no processo de tradução e publicação de Clarice pela editora Des femmes, quando a escritora ganhou projeção internacional. No entanto os textos de Cixous sobre Clarice, subjetivos e poéticos, demonstram uma paixão criticada por Lúcia Peixoto Cherem: "Este tipo de texto contribuiu para marcar a crítica de Cixous como algo despropositado, subjetivo ao extremo, sem interesse algum para entender a obra da escritora brasileira" (: 31$)$.

Embora a autora da tese tenha algumas boas intuições sobre tradução, e sobretudo acerca da experiência de traduzir, na parte em que analisa as traduções de Clarice para o francês lhe falta uma teoria da tradução mais sólida. Há referências de segunda mão ao texto sobre tradução de Walter Benjamin, e outros autores canônicos, entre os quais Haroldo de Campos, não são mencionados.

Na parte de análise literária, há algumas afirmações ingênuas, embora em outros momentos a autora da tese demonstre muita argúcia sobre o mesmo assunto. Ao afirmar que é no real que Clarice está, "é na vida mesmo, na sua pulsação, sem que se precise de malabarismos teóricos para ter um contato frutífero com seu texto" (: 2), a autora parece desconhecer que literatura é mediação, e que mesmo a experiência vivida, ao ser contada, é recriada pela linguagem. Não há como detectar o real, não há como dizer que um escritor está mais próximo ou mais distante do real. Em outras passagens, todavia, o raciocínio é muito mais sofisticado, como, por exemplo, nesta passagem: "A linguagem é a arma com a qual Clarice e seus leitores contam para dar sentido à vida, mesmo sabendo que esse sentido nunca chega a ser captado" (: 16).

Há algumas afirmações um pouco desconcertantes em relação ao que a autora entende por literatura, tradição literária e crítica literária: "Clarice nos transmite as idéias de provisoriedade e precariedade do universo em que se vive e não aquelas de um mundo protegido e estabelecido que uma literatura já consagrada poderia oferecer, repetindo fórmulas que haviam dado certo" (: 78). Caso se faça referência à tradição do romance moderno, que começa com Cervantes, nenhum grande escritor descreveu um "mundo protegido e estabelecido" e tampouco repetiu "fórmulas que haviam dado certo". Cada um mudou alguma coisa em relação ao anterior. É preciso destacar ainda que Clarice escreve depois das grandes rupturas no gênero feitas por Kafka, Joyce, Faulkner e tantos outros. 
A autora da tese faz também uma associação bastante curiosa entre o mundo acadêmico, que privilegiaria o intelecto e o conhecimento, em detrimento da intuição e da emoção. Ela parece duvidar da capacidade da crítica de dar conta de todo o emaranhado existente entre emoção, subjetividade e análise. "Mas, não há como negar que o conceitual, em literatura, sempre foi mais valorizado que o sensorial e, por isso, talvez, parte da crítica literária brasileira [...] tenha sido mais receptiva a seus contos [...]" (: 92). Segundo Cherem, haveria, "na França e no Quebec, uma vontade de ruptura com a crítica intelectualizada, muito distanciada, às vezes, da leitura prazerosa e vibrante que se fez da obra" (: 131). Nesse sentido, ela afirma que Cixous, Varin e Bosco tentam "criar um espaço na crítica literária que leve em conta, além do intelecto, também a intuição do crítico e sua empatia com os autores estudados, sem que seja necessário construir um sistema para explicar a inserção desses escritores numa determinada literatura, seja do ponto de vista sociológico, seja filosófico ou estético" (: 50). Há, porém, que se distinguir entre o prazer da leitura e o discurso que se escreve a posteriori sobre o texto, sendo necessário indagar se a oposição entre conceitual e sensorial existiria na literatura ou na crítica literária, já que esta, sendo uma metalinguagem - um discurso sobre a literatura - precisa ser "conceitual" e não "sensorial".

$\mathrm{Na}$ conclusão, depois de dizer que nas artes plásticas "parece estar surgindo o momento para que o sentimento, a intuição e a gratuidade reganhem a cena" (: 180), a autora afirma que o número maior de mulheres em atividade teria contribuído "para uma reavaliação de procedimentos exageradamente intelectualizados, mais tradicionais, e que foram, por muito tempo, o alicerce de toda a história ocidental" (: 180). Nesta frase, parece estar implícita uma visão patriarcal, falocêntrica, que tem norteado a oposição clássica entre o homem como detentor do pensamento lógico e racional e a mulher como o ser irracional/sensorial/intuitivo.

A autora da tese acredita que o endeusamento e a mitificação de Clarice na França e no Quebec seriam maiores que no Brasil (: 30 a 32). "Para certos leitores, a espiritualidade desenvolvida por Clarice, em parte de sua obra, talvez represente um substitutivo para uma crença religiosa tradicional. Para algumas francesas e canadenses, conhecer a obra de Lispector talvez tenha coincidido com a busca de uma espiritualidade secularizada" (: 65).

A tese, apesar de alguns senões aqui levantados, tem valor e merece ser publicada, devendo para isso haver alguns cortes e ater-se à questão proposta, qual seja, a da recepção da obra de Clarice Lispector na França e no Quebec, desenvolvendo-a ainda mais.

Eurídice Figueiredo

[UFF] 